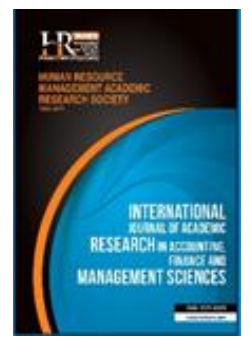

International Journal of Academic Research in Accounting, Finance and Management Sciences

Vol. 9, No.3, July 2019, pp. 59-69

E-ISSN: 2225-8329, P-ISSN: 2308-0337

(C) 2019 HRMARS

www.hrmars.com

To cite this article: Al-Mawsheki, R. M. S. A., Ahmad, N. B., Nordin, N. B. (2019). The Effects of Efficient Working Capital Management and Working Capital Policies on Firm Performance: Evidence from Malaysian Manufacturing Firms, International Journal of Academic Research in Accounting, Finance and Management Sciences 9 (3): 59-69.

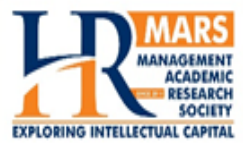

EXPLORING INTELIECTUAL CAPTTIA

\title{
The Effects of Efficient Working Capital Management and Working Capital Policies on Firm Performance: Evidence from Malaysian Manufacturing Firms
}

\author{
Randa Mohammed Shams Addin Al-Mawsheki ${ }^{1}$, Norzalina Binti Ahmad ${ }^{2}$, \\ Norhafiza Binti Nordin ${ }^{3}$
}

School of Economics, Finance and Banking, University Utara Malaysia (UUM), Malaysia, E-mail: super_rand@yahoo.com (Corresponding author)

\begin{abstract}
This study investigates the effect of efficient working capital management and working capital policies on the performance of manufacturing firms in Malaysia between 2010 and 2016. To achieve the objective, this study uses balanced panel data of 143 manufacturing firms that are listed on the Main Market of Bursa Malaysia. The results show that cash conversion cycle, which is used as a proxy of efficiency working capital management, is significantly negative in having an effect on the economic value added, which is used as a proxy of firm performance. Moreover, the results show that the ratio of current assets to total asset, which is used as a proxy of working capital investment policy, has a significant and positive effect on the firm performance. However, the results show that the ratio of current liabilities to total asset, which is used as a proxy of working capital financing policy, has no effect on the firm performance. The results of the study imply that the manufacturing firms in Malaysia can increase their economic value added by adopting efficient working capital management which is to reduce their cash conversion cycle. In addition, the manufacturing firms in Malaysia can improve their economic value added by adopting a conservative working capital investment policy.

Key words Economic Value Added, Efficiency Working Capital Management, Working Capital Policies, Firm Performance

Received: 10 Aug 2019 (C) The Authors 2019

Revised: 08 Sep 2019 Published by Human Resource Management Academic Research Society (www.hrmars.com)

Accepted: 22 Sep 2019 This article is published under the Creative Commons Attribution (CC BY 4.0) license. Anyone may Published Online: 27 Sep 2019 reproduce, distribute, translate and create derivative works of this article (for both commercial and non-commercial purposes), subject to full attribution to the original publication and authors. The full terms of this license may be seen at: http://creativecommons.org/licences/by/4.0/legalcode
\end{abstract}

\section{Introduction}

Working capital management (WCM) is important in all sectors of economic activity for various reasons. One reason is the impact of working capital on the liquidity of firms and, consequently, on their financial performance (Richards and Laughlin, 1980). WCM includes decisions on the quantity and the formation of the elements of current assets and current liabilities (Gul et al., 2013). These decisions on the quantity of current assets and current liabilities usually depend on the working capital policy (WCP) that a firm adopts. Weinraub and Visscher (1998); Darwish, (2014) classified WCP into aggressive and conservative categories; based on working capital investment policy (WCIP) and working capital financing policy (WCFP). Both WCIP and WCFP are directly related to the risks and return trade-off policy of the firm (Weinraub and Visscher, 1998). 
If a firm keeps few current assets compared to its total assets, this indicates an aggressive WCIP. Aggressive WCIP leads to increased profitability because of more investments in fixed assets but, at the same time, leads to reduce liquidity and increase potential problems in solvency and default risk (Weinraub and Visscher, 1998; Nazir and Afza, 2009). However, if a firm keeps high level of current assets compared to total assets, this then indicates the adoption of a conservative WCIP. Keeping a high level of current assets means that a high level of liquidity exists, which helps a firm to avoid any potential liquidity problems. Nevertheless, high level of liquidity prevents a firm from achieving profits that might have resulted if this this liquidity had been invested (Aktas et al., 2015).

The level of current liabilities on the balance sheet reflects WCFP. If a firm uses a high level of current liabilities compared to total assets, this then means that the firm prefers to finance its financial obligations more through short- term financing sources than through long- term financing sources, and this, in turn, indicates an aggressive WCFP. The cost of using short- term financing sources can be less than the cost of long- term financing sources (Weinraub and Visscher, 1998). However, the exposed risk from short- term financing sources can be higher than exposed risk from long- term financing sources, as the firm has to settle these obligations in the short term (Walker, 1964).

Conversely, a conservative WCFP refers to a low level of short- term liabilities compared to total liabilities. A high level of long- term liabilities leads to fewer risks relating to the necessity of paying them back in the short term (Walker, 1964). However, the cost of using long- term financing sources by a firm could be higher than the cost of short- term financing sources. A firm that uses equity or long- term debt more than short- term debts has a high of cost of capital (Weinraub and Visscher, 1998). Consequently, the type of WCP (aggressive or conservative) affects the cost of capital and value of a firm.

Managers try to keep an optimal level of the working capital while simultaneously try to manage it efficiently in order to achieve a positive value for a firm which sometimes is a difficult task (Deloof, 2003). Most of the literature has pointed out that firms attempt to manage their working capital efficiently through reducing the cash conversion cycle (CCC). Richards and Laughlin (1980) defined CCC as the net period interval between a firm's cash expenditures for the purchase of productive resources and the cash flow recovery from the product sales. By reducing the CCC, firms could create an internal fund that enhances their financial flexibility and enables the mitigation of the dependence on external financial resources. Reducing the need for external financing resources leads to the reduction of the potential costs of capital and consequently improves a firm's value (Ebben and Johnson, 2011; Almeida and Eid, 2014; Yazdanfar and Öhman, 2014). Hence, managers must take into consideration both the CCC of firms and the WCP in order to have a positive impact on a firm's cost of capital, profitability and value.

WCM is undeniably important for manufacturing firms. Fazzari and Petersen (1993) pointed out that in modern manufacturing firms; the components of working capital are more than half as large as the total assets. Manufacturing firms usually tend to keep a huge inventory to sustain their operations (Hawawini et al., 1986). In contrast, other sectors like service sector are not burdened by the need to maintain inventories because of nature of sector, which depends on offering services and not tangible products. Additionally, manufacturing firms typically utilize credit policy widely to sell their products and achieve high profitability, which, in turn, leads to increased receivables accounts. Selling their products on credit might produce increased sales levels but not taking cash immediately may affect the liquidity position in the short term and could cause insolvency or bankruptcy. On other hand, manufacturing firms need to buy raw materials for their operations and are often required to pay cash or delay the payments in the form of payable liabilities. Therefore, the importance of WCM (management of inventories, receivables and payables) in manufacturing firms has made these firms to pay great attention to it.

Improving the financial performance of firms is the major goal of all business firms, irrespective of their nature of business or what kind of firms they are. The financial performance of a firm is usually measured using traditional profitability metrics such as return on investment, return on equity and earnings per share. However, the use of traditional profitability tools alone is insufficient because they are less related to the wealth creation of shareholders (Naghshbandi et al., 2016).

Some studies have classified financial performance metrics into accounting-based and value-based measures. Accounting-based measures refer to profitability measures such as: return on asset, return on equity, operational profit and etc. Value-based measures refer to measures of performance that relate to 
shareholder value creation (Naghshbandi et al., 2016). In 1990s Stern Stewart \& Company came out with a new metric "Economic Value Added (EVA)" that, according to them, drives stock prices, creates wealth and can explain the changes in shareholder value in a better possible way than other profitability performance measures (Stewart, 1994). EVA is measured by deducting the capital charge from the net operating profit after tax (NOPAT). Hence, EVA does not only measure the profit generated from the operations but also considers the cost of capital invested by a firm; this makes EVA distinct from other traditional profitability measurements. Studying the effect of WCM on the financial performance of a firm by using EVA as a measurement of the financial performance has important value for many reasons. One reason is the advantages that EVA offers in measuring both profitability and cost of capital. This enables an investigation of how WCM affects both profitability and cost of capital. Another reason is the higher correlation of EVA to the wealth of shareholders than other more traditional measures (Bacidore et al., 1997; Chen and Dodd, 1997; Naghshbandi et al., 2016). Thus, using EVA as a measurement of the firm's performance could reflect upon how WCM influences the creation of value for shareholders.

In Malaysia, the manufacturing sector makes a vital contribution to the competitiveness and prosperity of the economy. The manufacturing sector is the second largest contributor to the gross domestic product (GDP) of Malaysia and overall growth after the services sector (BNM Annual Report, 2016). The manufacturing sector is expected to comprise about $28.5 \%$ of gross domestic product (GDP) in 2020 with average annual growth of $5.6 \%$. Thus, without doubt, focusing on the improvement of the performance of manufacturing sector is needed. Previous studies have found a strong relationship between WCM and the financial performance of Malaysian manufacturing firms (see for example, Zariyawati et al., 2009; Wasiuzzaman, 2015; Jakpar et al., 2017; and Ng et al., 2017). Nevertheless, these studies only focused on the effect of the WCM on the profitability of a firm not on its value. Therefore, this study intends to fill the gap of extant literature by examining the effect of WCM on the firm performance (represented by EVA). This study focuses in two sides of WCM, which are efficiency WCM (represented by CCC) and WCP (represented by both of WCIP and WCFP).

\section{Literature Review}

Although the literature shows a strong relationship between efficient WCM and the performance of a firm, this relationship is often not straight forward. Some researchers have found that an efficient WCM via a short CCC was better for a firm to adopt because possible negative effects of a long CCC existed, which negatively affected firm performance. For example, a longer CCC that has resulted from an increase in the inventories conversion period in the investment of inventories leads to rising costs such as warehouse rents, insurance and loss of income due to the possibility of reduced demand (Kieschnick et al., 2013). These expenses bring about additional capital requirements, which the firms must finance and involve financing costs and opportunity costs. However, firms with a longer CCC are able to stimulate sales (BanosCaballero et al., 2013). Higher sales could be achieved if a firm follows inefficient WCM because a larger investment in receivables that causes a longer CCC (Sharma and Kumar, 2011). Additionally, an increase in extended trade credits allows a firm to serve its customers better and increases the number of customers. Extended trade credits also play a role in strengthening the relationship between suppliers and customers over the long term. It is a way of verifying product quality before making a payment, and, consequently, reducing the asymmetric information between the buyer and the supplier (Summers and Wilson, 2000).

Most of the extant empirical studies have focused on the effect of WCM on a firm's profitability and not too much on a firm's value. However, increasing profitability represents a short- term goal of firms but maximizing the value of the firms is a long- term. A firm could achieve value and maximize their shareholder's value if a firm can improve its operational profit and reduce its cost of capital as well (Bacidore et al., 1997). Thus, a firm should focus not only on profit maximization but also on how to reduce the cost of capital to achieve high value. Economic value added (EVA) is a measure of financial performance that can reflect both operational profitability and cost of capital of the firm. If EVA is positive, then a firm achieves profits from its operations while simultaneously being able to cover the cost of capital. Nevertheless, if EVA is negative, then a firm may achieve profits from their operation but cannot cover the cost of capital (Bacidore et al., 1997; Naghshbandi et al., 2016). A few studies have pointed out a link between WCM and the cost of capital and consequently the firm value (see for example, Ebben and 
Johnson, 2011; Almeida and Eid, 2014; Yazdanfar and Öhman, 2014). However, most of the past empirical studies ignored the effect of WCM on the cost of capital and hence on EVA and have only focused on the firm's profitability. In addition, few studies exist in the Malaysian scenario especially in the manufacturing sector. Therefore, a need exists to do more studies on the effects of WCM on the EVA of manufacturing firms in Malaysia. Table 1 provides a summary of past empirical studies that have focused on the effect of WCM on the financial performance of a firm.

Table 1. Summary of past empirical studies

\begin{tabular}{|c|c|c|c|c|c|c|}
\hline Author(s) & Country & Sample size & $\begin{array}{l}\text { Period } \\
\text { of } \\
\text { study }\end{array}$ & $\begin{array}{l}\text { Measurement (s) of the } \\
\text { financial performance } \\
\text { (dependent variable) }\end{array}$ & $\begin{array}{l}\text { Measurement } \\
\text { (s) of the WCM } \\
\text { (Independent } \\
\text { variables) }\end{array}$ & $\begin{array}{c}\text { Results of } \\
\text { relationship } \\
\text { between WCM } \\
\text { and firm's } \\
\text { performance } \\
\end{array}$ \\
\hline Deloof (2003) & Belgium & $\begin{array}{l}1,009 \text { non- financial } \\
\text { firms }\end{array}$ & $\begin{array}{l}(1992- \\
1996)\end{array}$ & Gross operating income & $\mathrm{CCC}$ & $(-)$ sig. \\
\hline $\begin{array}{l}\text { Lazaridis } \quad \& \\
\text { Tryfonidis } \\
\text { (2006) }\end{array}$ & Athena & $\begin{array}{l}\text { 131firms listed in the } \\
\text { Athens stock exchange }\end{array}$ & $\begin{array}{l}(2001- \\
2004)\end{array}$ & Gross operating income & $\mathrm{CCC}$ & $(-)$ sig. \\
\hline $\begin{array}{l}\text { Juan Garcia- } \\
\text { Teruel } \quad \& \\
\text { Martinez- } \\
\text { Solano (2007) }\end{array}$ & Spain & 8,872 SME firms & $\begin{array}{l}(1996- \\
2002)\end{array}$ & Return on assets & $\mathrm{CCC}$ & $(-)$ sig. \\
\hline $\begin{array}{l}\text { Raheman, Afza, } \\
\text { Qayyum, \& } \\
\text { Bodla (2010) }\end{array}$ & Pakistan & $\begin{array}{l}204 \quad \text { Manufacturing } \\
\text { firms }\end{array}$ & $\begin{array}{l}(1998- \\
2007)\end{array}$ & Net operating profitability & $\begin{array}{l}\text { CCC } \\
\text { WCIP } \\
\text { WCFI }\end{array}$ & $\begin{array}{l}\text { (-) sig. with CCC } \\
(+) \text { sig. with WCIP } \\
(-) \text { sig. with WCFP }\end{array}$ \\
\hline Alipour (2011) & Iran & $\begin{array}{l}1063 \text { Non-financial } \\
\text { firms }\end{array}$ & $\begin{array}{l}(2001- \\
2006)\end{array}$ & Gross operating income & $\mathrm{CCC}$ & $(-)$ sig. \\
\hline $\begin{array}{l}\text { Nobanee et al. } \\
\text { (2011) }\end{array}$ & Japan & $\begin{array}{l}\text { 2,123 Japanese non- } \\
\text { financial firms }\end{array}$ & $\begin{array}{l}(1990- \\
2004)\end{array}$ & Return on investment & $\mathrm{CCC}$ & $(-)$ sig. \\
\hline $\begin{array}{l}\text { Sharma \& } \\
\text { Kumar (2011) }\end{array}$ & India & 263 Non-financial firms & $\begin{array}{l}(2000- \\
2008)\end{array}$ & Return on assets & $\mathrm{CCC}$ & $(+)$ not sig. \\
\hline $\begin{array}{l}\text { Charitou et al. } \\
\text { (2012) }\end{array}$ & Indonesia & $\begin{array}{l}\text { All firms listed in the } \\
\text { Indonesian stock } \\
\text { exchange }\end{array}$ & $\begin{array}{l}(1998- \\
2010)\end{array}$ & Return on assets & $\mathrm{CCC}$ & (+) sig. \\
\hline $\begin{array}{l}\text { Kaddumi } \quad \& \\
\text { Ramadan (2012) }\end{array}$ & Jordan & $\begin{array}{l}49 \text { Industrial firms } \\
\text { listed at Amman stock } \\
\text { exchange }\end{array}$ & $\begin{array}{l}(2005- \\
2009)\end{array}$ & $\begin{array}{l}\text { - Return on assets } \\
\text {-Net operating profitability }\end{array}$ & $\mathrm{CCC}$ & $(-)$ sig. \\
\hline Gul et al. (2013) & Pakistan & SME's firms & $\begin{array}{l}(2006- \\
2012)\end{array}$ & Return on assets & $\mathrm{CCC}$ & $(-)$ sig. \\
\hline $\begin{array}{l}\text { Enqvist, Graham } \\
\& \quad \text { Nikkinen } \\
(2014)\end{array}$ & Finland & Finnish listed firms & $\begin{array}{l}(1990- \\
2008)\end{array}$ & $\begin{array}{l}\text { - Return on assets } \\
\text { - Gross operating income }\end{array}$ & $\mathrm{CCC}$ & $(-)$ sig. \\
\hline $\begin{array}{l}\text { Muscettola } \\
(2014)\end{array}$ & Italy & $\begin{array}{l}4,226 \text { manufacturing } \\
\text { SMEs }\end{array}$ & $\begin{array}{l}(2007- \\
2010)\end{array}$ & $\begin{array}{l}\text { Earnings before interest, } \\
\text { taxes, depreciation and } \\
\text { amortization/net sales }\end{array}$ & $\mathrm{CCC}$ & $(+)$ sig \\
\hline Ukaegbu (2014) & $\begin{array}{l}\text { South Africa, } \\
\text { Nigeria, } \\
\text { Egypt and } \\
\text { Kenya }\end{array}$ & Industrial firms & $\begin{array}{l}(2005- \\
2009)\end{array}$ & Net operating profit & $\mathrm{CCC}$ & $(-)$ sig. \\
\hline $\begin{array}{l}\text { Yazdanfar \& } \\
\text { Öhman (2014) }\end{array}$ & Sweden & SME firms & $\begin{array}{l}(2008- \\
2011)\end{array}$ & Return on assets & $\mathrm{CCC}$ & $(-)$ sig. \\
\hline $\begin{array}{l}\text { Takon \& Atseye } \\
\text { (2015) }\end{array}$ & Nigeria & $\begin{array}{l}46 \text { firms listed on the } \\
\text { Nigeria Stock Exchange }\end{array}$ & $\begin{array}{l}(2000- \\
2009)\end{array}$ & Return on assets & $\mathrm{CCC}$ & $(-)$ sig. \\
\hline $\begin{array}{l}\text { Garanina \& } \\
\text { Petrova (2015) }\end{array}$ & Russia & $\begin{array}{l}720 \text { firms from services } \\
\text { and productions } \\
\text { sectors }\end{array}$ & $\begin{array}{l}(2001- \\
2012)\end{array}$ & $\begin{array}{l}\text { Return on net operating } \\
\text { assets }\end{array}$ & $\mathrm{CCC}$ & $(-)$ sig. \\
\hline $\begin{array}{l}\text { Vahid, Mohsen } \\
\& \\
\text { Mohammadreza } \\
\text { (2012) }\end{array}$ & Iran & $\begin{array}{l}28 \text { of Vehicles and } \\
\text { parts manufacturing } \\
\text { firms }\end{array}$ & $\begin{array}{l}(2005- \\
2009)\end{array}$ & $\begin{array}{l}\text {-Tobin's Q } \\
\text { - Return on assets }\end{array}$ & $\begin{array}{l}\text { WCIP } \\
\text { WCFP }\end{array}$ & $\begin{array}{l}(-) \text { sig. with WCIP } \\
(-) \text { sig. with WCFP }\end{array}$ \\
\hline $\begin{array}{l}\text { Bhatia } \quad \& \\
\text { Srivastava } \\
(2016)\end{array}$ & India & $\begin{array}{l}179 \text { firms listed on the } \\
\text { S\&P BSE } 500 \text { Index of } \\
\text { Bombay } \\
\text { Exchange }\end{array}$ & $\begin{array}{l}(2000- \\
2014)\end{array}$ & $\begin{array}{l}\text {-Tobin's Q } \\
\text {-Gross operating profit }\end{array}$ & $\mathrm{CCC}$ & $(-)$ sig. \\
\hline $\begin{array}{l}\text { Nazir \& Afza } \\
(2009)\end{array}$ & Pakistan & $\begin{array}{l}\text { Non-financial Pakistani } \\
\text { firms }\end{array}$ & $\begin{array}{l}(1998- \\
2005)\end{array}$ & $\begin{array}{l}\text {-Tobin's Q } \\
\text { - Return on assets }\end{array}$ & $\begin{array}{l}\text { WCIP } \\
\text { WCFP }\end{array}$ & $\begin{array}{l}\text { WCIP : (+) sig with } \\
\text { ROA and Tobin's } \\
Q\end{array}$ \\
\hline
\end{tabular}




\begin{tabular}{|c|c|c|c|c|c|c|}
\hline & & & & & & $\begin{array}{l}\text { with ROA and (+) } \\
\text { sig. with Tobin's Q }\end{array}$ \\
\hline $\begin{array}{l}\text { Zariyawati et al. } \\
\text { (2009) }\end{array}$ & Malaysia & 148 Non-financial firms & $\begin{array}{l}(1996- \\
2006)\end{array}$ & $\begin{array}{l}\text { (Operating income }+ \\
\text { depreciation)/total asset }\end{array}$ & $\mathrm{CCC}$ & $(-)$ sig. \\
\hline $\begin{array}{l}\text { Mohamad \& } \\
\text { Saad (2010) }\end{array}$ & Malaysia & 172 Non-financial firms & $\begin{array}{l}(2003- \\
2007)\end{array}$ & $\begin{array}{l}\text {-Tobin's Q } \\
\text { - Return on assets } \\
\text { - Return on invested capital }\end{array}$ & $\begin{array}{l}\text { - CCC } \\
\text { - WCIP } \\
\text { - WCFP }\end{array}$ & $\begin{array}{l}(-) \text { sig. with CCC } \\
(-) \text { sig. with WCFP } \\
(+) \text { sig with WCIP }\end{array}$ \\
\hline Ng et al. (2017) & Malaysia & 122 Manufacturing & $\begin{array}{l}(2007- \\
2012)\end{array}$ & Gross operating income & $\begin{array}{l}\text { CCC } \\
\text { WCIP } \\
\text { WCFP }\end{array}$ & $\begin{array}{l}(+) \text { sig. with CCC } \\
(+) \text { sig with WCIP } \\
(+) \text { sig with WCFP }\end{array}$ \\
\hline $\begin{array}{l}\text { Jakpar et al. } \\
(2017)\end{array}$ & Malaysia & 164 Manufacturing & $\begin{array}{l}(2007- \\
2011)\end{array}$ & Return on assets & $\mathrm{CCC}$ & $(-)$ sig. \\
\hline
\end{tabular}

Note: Source: compiled by the authors.

\section{Methodology of Research}

This study aims to examine the effect of WCM on the firm performance. To achieve this aim, this study conducted a panel regression analysis of 959 observations for manufacturing firms in Malaysia from 2010 to 2016. Figure 1 illustrates the framework of this study.

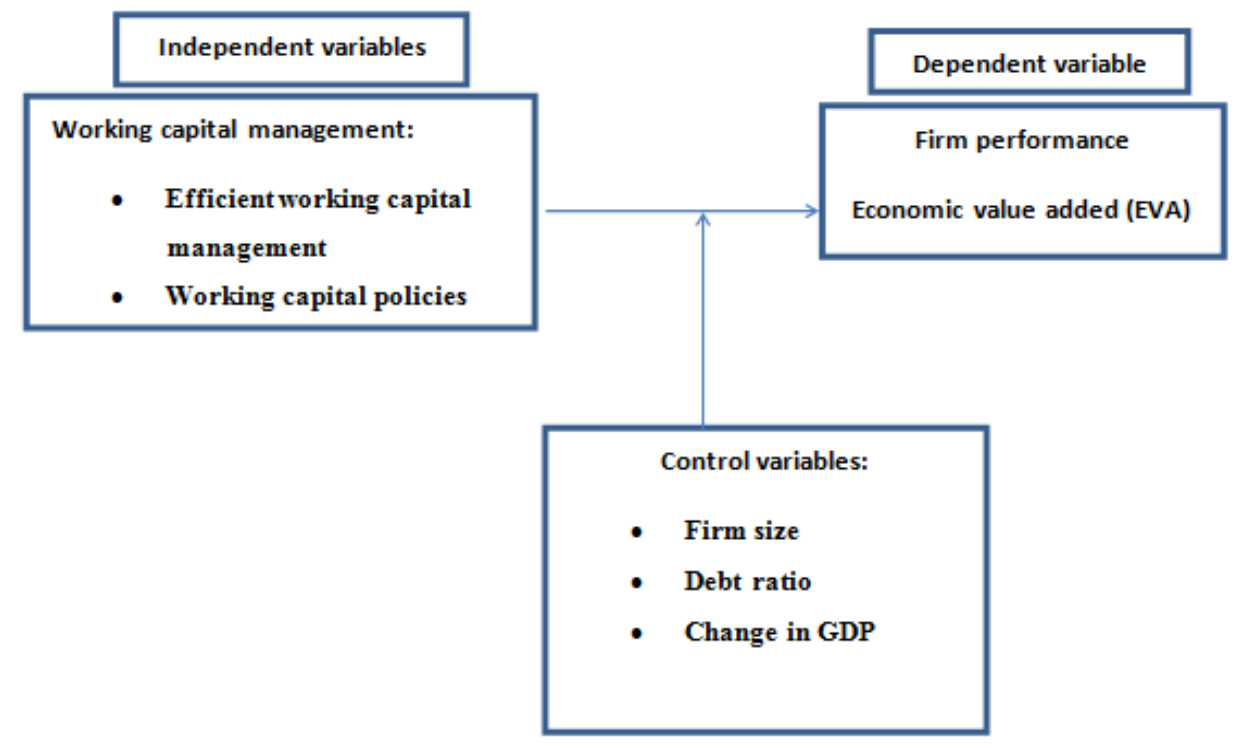

Figure 1. Theoretical Framework

Based on the above rationale, this study proposes the following three hypotheses:

Hypothesis 1. A significant and negative relationship will exist between efficient WCM measured by CCC and firm performance.

Hypothesis 2. A significant relationship will exist between WCIP measured by the CATA ratio and firm performance.

Hypothesis 3. A significant relationship will exist between WCFP measured by the CLTA ratio and firm performance.

\subsection{Sample and Data}

The population of this study was all manufacturing firms listed on the Main Market of Bursa Malaysia. The data was collected for the period from 2010 to 2016 from annual reports of the firms, Thomson Reuters Eikon and DataStream. This study excluded firms that had missing data during the period of study. Additionally, this study excluded firms that had engaged in mergers and acquisitions or firms established after 2010. The final sample was 137 firms that had complete data for all variables during the period from 2010 until 2016. Moreover, firm size (SIZE) was transformed using natural logarithm, while other variables were winsorized at the $5 \%$ and $95 \%$ levels in order to mitigate the influences of outliers.

Variables 
The model regression used in this study is as follows:

$\mathrm{EVA}_{i t}=\beta_{0}+\beta_{1} \mathrm{CCC}_{i t}+\beta_{2} \mathrm{CATA}_{i t}+\beta_{3} \mathrm{CLTA}_{i t}+\beta_{4} \mathrm{DR}_{i t}+\beta_{5} \mathrm{SIZE}_{i t}+\beta_{6} \mathrm{GDP}_{i t}+e_{i t}$

Where,

EVA: economic value added

CCC: cash conversion cycle (inventories conversion period + receivables collecting period - account payable period).

CATA: current asset to total asset ratio

CLTA: current liabilities to total asset ratio

DR: debt ratio (total debt divided by total asset)

SIZE: firm size (logarithm of sale)

GDP: change in the gross domestic product of Malaysia

$\beta 0$ : the intercept of the equation

$\beta 1 \ldots \beta 4$ : the change coefficient for the variables

e: error term

The model is applied for each firm $(i)$ and each year $(t)$

Moreover, the dependent variable (EVA) that represents the firm performance based on value is calculated by the following equation:

$E V A=$ NOPAT $-(I C \times$ WACC $)$

Where, EVA is the economic value added. NOPAT is net operating before interest expenses and after tax. IC is the invested capital measured by the total of equity and the total interest bearing debt. WACC is the weighted average cost of capital measured by the total of weighted cost of debt and weighted cost of equity.

\section{Results and discussions}

\subsection{Descriptive Statistical Analysis}

The purpose of descriptive statistical analysis was to describe the raw data in an easily and interpretable form. Table 2 provides a summary of the data statistics of the seven focused variables for manufacturing firms in Malaysia for the period from 2010- 2016. Starting with the dependent variable (EVA), the average of EVA was RM -0.267 billion. The negative value of EVA gives an indication that the cost of capital for manufacturing firms in Malaysia is more than their achieved operation profit. The minimum value and maximum value of EVA was RM -12.002 billion and RM 8.865 billion respectively. The standard deviation of EVA was 1.146 billion.

Additionally, the average value of CCC was 140.6 days, which reflects the average period spent to collect receivables, convert inventories to sales and pay suppliers. The minimum value of CCC was -89.87 the negative value indicates a long payable period, which exceeds both periods of inventories conversion and receivables collection. That means some of manufacturing firms delay their payments to their debtors as long as possible and convert their inventories to sales in a short time while simultaneously collecting money from clients quickly, which reflects the efficiency in WCM. However, the maximum value of CCC was 856.98 days was an extremely long period of the CCC reflecting the inefficiency WCM in some Malaysian manufacturing firms.

The average of CATA was 0.53 , which means that more than $50 \%$ of total assets are invested in current assets by Malaysian manufacturing firms. This value of CATA ratio corresponds with that of Fazzari and Petersen (1993) who pointed that more than $50 \%$ of total assets of modern manufacturing firms are invested in form of current assets. Additionally, the high percentage of the average CATA gives an indication that manufacturing firms in Malaysia prefer to keep high levels of liquidity (represented by the big portion of current assets) and thereby, follow a conservative WCIP. Table 2 also shows that the average of CLTA was 0.33 , which means the manufacturing firms in Malaysia tend to meet their financial needs by $33 \%$ of short- term financing sources and $67 \%$ by long- term financing sources. This low level of the current liabilities gives an indication that the manufacturing firms follow a conservative WCFP. The variation between the minimum and maximum values of both the CATA ratio and CLTA ratio reflect the difference in WCP adopted by Malaysian manufacturing firms. Moreover, to describe the control variables of this study, 
the mean of DR was $22 \%$ which means that the firms, on average, tend to use financing sources such as equities more than debts. The mean of sales achieved by the firms (SIZE) was RM 0.564 billion. Additionally, the average of change in GDP growth was 5.4 while, the minimum value of 4.2 was recorded in 2016 and the maximum value of 7.2 was recorded in $2010^{1}$.

Table 2. Summary Statistics ( $n=959)$

\begin{tabular}{|c|c|c|c|c|}
\hline & Mean & St.Dev & Min & Max \\
\hline EVA (in billion) & -0.267 & 1.146 & -12.002 & 8.864 \\
\hline $\mathrm{CCC}$ & 140.58 & 99.22 & -89.87 & 856.98 \\
\hline CATA & 0.53 & 0.18 & 0.00 & 0.98 \\
\hline CLTA & 0.33 & 0.15 & 0.04 & 0.81 \\
\hline DR & 0.22 & 0.14 & 0.00 & 0.65 \\
\hline SIZE (in billion) & 0.564 & 0.859 & 0.005 & 6.649 \\
\hline GDP & 5.4 & 0.91 & 4.2 & 7.2 \\
\hline
\end{tabular}

Note: The dependent variable is firm performance measured by EVA (in billion). CCC is the cash conversion cycle reflecting the efficiency of WCM. CATA is the ratio of current assets to total assets, which reflects the investment policy in short term. CLTA represents the ratio of current liabilities to total assets, which reflects the financing policy in short term. SIZE represents firm size in terms of total sale (in billion). GDP represents the ratio of gross domestic product change in Malaysia.

\subsection{Correlation Analysis}

The purpose of correlation analysis is to detect any high correlation between two independent variables that might leads to a multicollinearity problem in the model and consequently cause biased results (Gujarati and Porter, 2009). However, correlational analysis is limited and does not examine the causal relationship between variables (Ukaegbu, 2014; Bhatia and Srivastava, 2016). Based on Table 3, none of the variables had a correlation of more than 0.80 , which provides evidence that no multicollinearity problem existed (Gujarati and Porter, 2009).

Table 3. Pearson Correlation

\begin{tabular}{cccccccc}
\hline Variables & EVA & CCC & CATA & CLTA & SIZE & DR & GDP \\
\hline EVA & 1.000 & & & & & & \\
CCC & 0.017 & 1.000 & & & & & \\
CATA & $0.082^{*}$ & $0.216^{*}$ & 1.000 & & & & \\
CLTA & $0.071^{*}$ & $-0.179^{*}$ & $0.311^{*}$ & 1.000 & & & \\
SIZE & $-0.161^{*}$ & $-0.175^{*}$ & $-0.133^{*}$ & $0.205^{*}$ & 1.000 & & \\
DR & $0.075^{*}$ & 0.012 & $0.077^{*}$ & $0.685^{*}$ & $0.139^{*}$ & 1.000 & \\
GDP & $0.101^{*}$ & 0.058 & 0.005 & 0.039 & -0.038 & $0.067^{*}$ & 1.000 \\
\hline
\end{tabular}

* shows significance at the .05 level

\subsection{Regression Analysis}

This study tested the hypotheses on the effect of efficiency of WCM and WCP on EVA using STATA software Version 14. Panel data methodology was followed because of the nature of data of this study and because of many advantages of panel data as well. According to Gujarati and Porter (2009), panel data allows controlling for any individual heterogeneity arising in a model due to the different characteristics of firms and, therefore, removes the risks of obtaining biased results. Additionally, panel data provides more variability, more degrees of freedom, efficiency and less collinearity between variables (Gujarati and Porter, 2009).

\footnotetext{
${ }^{1}$ Computed from the annual report of Bank Negara Malaysia (2016)
} 
Individual heterogeneity was tested by conducting both the F-test (in order to choose between pooled ordinary least squares model and fixed- effect model) and the Breusch-Pagan Lagrangian Multiplier (LM) test (in order to choose between pooled ordinary least squares and random effect model). The results of these tests showed that an individual heterogeneity effect existed in the model, and therefore, the pooled ordinary least squares model was not chosen. Additionally, the Hausman test was conducted to determine if a correlation existed between the explanatory variables and the individual effects and, thereby, leading to a choice between a fixed effect estimation and random effect estimation. If there is a correlation, then the fixed effect model will be the fit model otherwise the random effect model will be the fit model. The result of the Hausman test showed an insignificant $p$-value, which means that no correlation existed between the explanatory variables and the individual effects. Therefore, this study chose the random effect model.

Moreover, in order to test the presence of any hetroscedasticity and autocorrelation problems, the Breusch-Pagan/Cook-Weisberg test and the Wooldridge test were conducted. The results of these tests showed the presence of both heteroscedasticity and autocorrelation problems, which must be treated. Accordingly, the model of this study was estimated as a random effects model and cluster standard errors at the firm level in order to treat both of hetroscedasticity and autocorrelation problems as suggested by Hoechle (2007) and Petersen (2009). Cluster standard error is one of techniques which used by last studies in order to treat both of hetroscedasticity and autocorrelation problems (see for example, Kieschnick et al., 2013; Aktas et al., 2015).

Table 4 shows the regression results. The overall $R^{2}$ of the model is $16.78 \%$ which means that the independent variables in this study could explain $16.78 \%$ of the firm performance measured by EVA. The Chi-square was 58.79 with $p$-value of 0.00 , which indicates to the significance of the model. Table 5 shows a negative and significant relationship between CCC and EVA. This negative and significant relationship between CCC and EVA means that a shorter CCC leads to increase the EVA of manufacturing firms in Malaysia. Any increase in CCC by 1day leads to a decrease in EVA by RM 0.0004 in billion. In contrast, any decrease in CCC by 1 day lead to increase in EVA by RM 0.0004 in billion. This result goes in line with the results of most previous studies, which revealed that there was a significant and negative relationship between CCC and firm performance. These include: Deloof (2003), Lazaridis and Tryfonidis (2006), GarciaTeruel and Martinez-Solano (2007), Zariyawati et al. (2009), Raheman et al. (2010), Alipour (2011), Nobanee et al. (2011), Kaddumi and Ramadan (2012), Gul et al. (2013), Enqvist et al. (2014), Bhatia and Srivastava (2016), Takon and Atseye (2015), Ukaegbu (2014), Yazdanfar and Öhman (2014), Garanina and Petrova (2015), Mohamad and Saad (2010), Jakpar et al. (2017).

Table 4. Regression Results

\begin{tabular}{|c|c|c|c|c|}
\hline EVA & Coef. & St. Error & t-value & $p$-value \\
\hline $\mathrm{CCC}$ & $-0.00043^{*}$ & 0.00025 & -1.67 & 0.094 \\
\hline CATA & $0.47591 * * *$ & 0.16491 & 2.89 & 0.004 \\
\hline CLTA & -0.01758 & 0.24808 & -0.07 & 0.944 \\
\hline DR & $0.68501 * *$ & 0.27146 & 2.52 & 0.012 \\
\hline GDP & $0.06716 * * *$ & 0.01441 & 4.66 & 0.000 \\
\hline SIZE & $-0.39166 * * *$ & 0.07206 & -5.44 & 0.000 \\
\hline _cons & $2.3338 * * *$ & 0.55549 & 4.20 & 0.000 \\
\hline Overall r-squared & 0.1678 & \multicolumn{2}{|c|}{ Number of observations } & 959 \\
\hline Chi-square & 58.79 & \multicolumn{2}{|c|}{ Prob > chi2 } & 0.000 \\
\hline $\begin{array}{l}* * * \text { significant at } 1 \% \\
* * \text { significant at } 5 \% \\
* \text { significant at } 10 \%\end{array}$ & & & & \\
\hline
\end{tabular}

The significant and negative relationship between CCC and EVA in this study, gives an indication that reducing the CCC not only leads to improved profitability, but, at the same time, reduces the cost of capital for manufacturing firms in Malaysia. This result corresponds with the pecking order theory. Based on the pecking order theory, firms tend to use internal financing sources more than external financing sources to 
reduce the costs related to financing and, therefore, improve the financial performance. Reducing the CCC provides an internal source of financing that has lower costs compared to the costs of external financing and, therefore, reducing the CCC leads to an increase in profitability, reduces the cost of capital and enhances the firm value. Therefore, the results support the first hypothesis in this study that a significant and negative relationship is more likely between efficient WCM measured by CCC and firm performance measured by EVA.

CATA and EVA had a positive relationship between each other, and this relationship was significant at the $1 \%$ level. This indicates that any increase/decrease in the ratio of current assets to total assets by $1 \%$, for example, more inventories and more accounts receivables, then EVA can be increase/decrease by RM 0.4759 in billion. This result corresponded with more previous studies like those of Nazir and Afza (2009), Mohamad and Saad (2010), Ng et al. (2017). The result supports the second hypothesis in this study that a significant relationship would exist between WCIP measured by the CATA ratio and firm performance measured by EVA.

Result of this study shows that CLTA and EVA had a positive but insignificant relationship with each other. This indicates that the ratio of current liabilities to total assets does not affect the firm performance measured by EVA. This result does not support the third hypothesis of this study in which a significant relationship was hypothesized to exist between WCFP measured by the CLTA ratio and firm performance measured by EVA. Therefore, firm performance does not affected by the WCFP.

Moreover, all of the control variables in this study had a significant effect on EVA. The relationship between firm size and EVA is significant and negative, which means that smaller firms with efficient WCM and conservative WCIP were likely to have better firm value. This result of negative and significant relationship between SIZE and firm performance is in line with the results found in Sharma and Kumar (2011), Enqvist et al. (2014). DR had a positive and significant relationship with EVA, which means that firms should use debt more than other capital components to maximize their EVA. This result of positive and significant relationship between DR and firm performance is in line with the results found in Nazir and Afza (2009), Mohamad and Saad (2010). GDP had a positive and significant relationship with EVA, which points to the significant impact of the condition of the Malaysian economy on firm value. This result is in line with the results found in Garcia-Teruel and Martinez-Solano (2007), Nazir and Afza (2009), Kieschnick et al. (2013).

\section{Conclusions}

This study presents empirical evidence for the effect of working capital management on the EVA of Malaysian manufacturing firms. WCP and efficient WCM have a significant effect not only on profitability but also on costs of capital and, consequently, on the value of firm. This study has several implications that may be relevant for managers and researchers in the field of WCM. First, based on the results of the study, managers of manufacturing firms in Malaysia should be concerned about cash conversion cycle and make it shorter to enhance the values of the firms. Second, the managers of manufacturing firms can enhance the value of firms by adopting conservative working capital investment policies. A big portion of current assets for the manufacturing firms need more attention from managers and presents an important task for them to manage in more efficiently way. In short, this study concludes that investing more in working capital (conservative WCIP) while managing of working capital efficiently (through reducing the CCC) would maximize the value of manufacturing firms in Malaysia.

\section{References}

1. Aktas, N., Croci, E., \& Petmezas, D. (2015). Is working capital management value-enhancing? Evidence from firm performance and investments. Journal of Corporate Finance, 30, 98-113.

2. Alipour, M. (2011). Working capital management and corporate profitability: Evidence from Iran. World Applied Sciences Journal, 12(7), 1093-1099.

3. Almeida, J. R., \& Eid, W. (2014). Access to finance, working capital management and company value: Evidences from Brazilian companies listed on BM \& FBOVESPA. Journal of Business Research, 67(5), 924-934. 
4. Bacidore, J. M., Boquist, J. A., Milbourn, T. T., \& Thakor, A. V. (1997). The search for the best financial performance measure. Financial Analysts Journal, 53(3), 11-20.

5. Bagh, T., Nazir, M. I., Khan, M. A., Khan, M. A., \& Razzaq, S. (2016). The Impact of Working Capital Management on Firms Financial Performance: Evidence from Pakistan. International Journal of Economics and Financial Issues, 6(3), 1097- 1105.

6. Bank Negara Malaysia. (2016). Bank Negara Malaysia annual report. Retrieved from http://www.bnm.gov.my/files/publication/ar/en/2016/ar2016_book.pdf

7. Baños- Caballero, S., García- Teruel, P. J., \& Martínez-Solano, P. (2013). Working capital management, corporate performance, and financial constraints. Journal of Business Research, 67(3), 332338.

8. Bhatia, S., \& Srivastava, A. (2016). Working capital management and firm performance in emerging economies: evidence from India. Management and Labour Studies, 41(2), 71-87.

9. Charitou, M., Lois, P., \& Santoso, H. B. (2012). The relationship between working capital management and firm's profitability: An empirical investigation for an emerging Asian country. The International Business \& Economics Research Journal, 11(8), 839-848.

10.Chen, S., \& Dodd, J. L. (1997). Economic value added (EVA $\left.{ }^{\mathrm{TM}}\right)$ : An empirical examination of a new corporate performance measure. Journal of Managerial Issues, 9(3) 318-333.

11. Darwish, S. (2014). Education and Human Capital Development in Bahrain:" Future International Collaboration with Malaysia. International Journal of Academic Research in Management (IJARM), 3(4), 321-334.

12.Deloof, M. (2003). Does working capital management affect profitability of Belgian firms. Journal of Business Finance \& Accounting, 30(3-4), 573-588.

13.Ebben, J. J., \& Johnson, A. C. (2011). Cash conversion cycle management in small firms: Relationships with liquidity, invested capital, and firm performance. Journal of Small Business \& Entrepreneurship, 24(3), 381-396.

14.Enqvist, J., Graham, M., \& Nikkinen, J. (2014). The impact of working capital management on firm profitability in different business cycles: Evidence from Finland. Research in International Business and Finance, 32, 36-49.

15.Fazzari, S. M., \& Petersen, B. C. (1993). Working capital and fixed investment: New evidence on financing constraints. The RAND Journal of Economics, Available Online: http://www.jstor.org/stable/ 2555961?seq=1\#page_scan_tab_contents

16.Garanina, T. A., \& Belova, O. A. (2015). Liquidity, cash conversion cycle and financial performance: case of Russian companies. Investment Management and Financial Innovations, 12(1), 90-100.

17.Gujarati, D. N. \& Porter, D. C. (2009). Basic econometrics. Chicago, IL: The McGraw-Hill/Irwin.

18.Gul, S., Khan, M. B., Rehman, S. U., Kahn, M. T., Khan, M., \& Khan, W. (2013). Working capital management and performance of SME sector. European Journal of Business and Management, 5(1), 60-68.

19. Hawawini, G., Viallet, C., \& Vora, A. (1986). Industry influence on corporate working capital decisions. Sloan Management Review, Available Online https://mpra.ub.uni-muenchen.de/44894/ 1/MPRA_paper_44894.pdf

20.Hoechle, D. (2007). Robust standard errors for panel regressions with cross-sectional dependence. The Stata Journal, 7(3), 281-312.

21.Jakpar, S., Tinggi, M., Siang, T., Johari, A., Myint, K., \& Sadique, M. (2017). Working capital management and profitability: Evidence from manufacturing sector in Malaysia. Journal of Business \& Financial Affairs, 6(2), 1-9.

22.Juan García-Teruel, P., \& Martinez-Solano, P. (2007). Effects of working capital management on SME profitability. International Journal of Managerial Finance, 3(2), 164-177.

23.Kaddumi, T. A., \& Ramadan, I. Z. (2012). Profitability and working capital management: The Jordanian case. International Journal of Economics and Finance, 4(4), 217-226.

24.Kieschnick, R., Laplante, M., \& Moussawi, R. (2013). Working capital management and shareholders' wealth. Review of Finance, 17(5), 1827-1852. 
25.Lazaridis, I., \& Tryfonidis, D. (2006). Relationship between working capital management and profitability of listed companies in the Athens stock exchange. Journal of Financial Management and Analysis, 19(1), 26-35.

26.Mohamad, N. E. A. B., \& Saad, N. B. M. (2010). Working capital management: The effect of market valuation and profitability in Malaysia. International Journal of Business and Management, 5(11), 140-147.

27.Mun, S. G., \& Jang, S. S. (2015). Working capital, cash holding, and profitability of restaurant firms. International Journal of Hospitality Management, 48, 1-11.

28. Muscettola, M. (2014). Cash conversion cycle and firm's profitability: An empirical analysis on a sample of 4,226 manufacturing SMEs of Italy. International Journal of Business and Management, 9(5), 2535.

29.Naghshbandi, N., Chouhan, V., \& Jain, P. (2016). Value based measurement of financial performance. International Journal of Applied Research, 2(2), 365-369.

30.Nazir, M. S., \& Afza, T. (2009). Impact of aggressive working capital management policy on firms' profitability. IUP Journal of Applied Finance, 15(8), 19-30.

31.Ng, S. H., Ye, C., San Ong, T., \& Teh, B. H. (2017). The impact of working capital management on firm's profitability: Evidence from Malaysian listed manufacturing firms. International Journal of Economics and Financial Issues, 7(3), 662-670.

32.Nobanee, H., Abdullatif, M., \& AlHajjar, M. (2011). Cash conversion cycle and firm's performance of Japanese firms. Asian Review of Accounting, 19(2), 147-156.

33.Petersen, M. A. (2009). Estimating standard errors in finance panel data sets: Comparing approaches. The Review of Financial Studies, 22(1), 435-480.

34.Raheman, A., Afza, T., Qayyum, A., \& Bodla, M. A. (2010). Working capital management and corporate performance of manufacturing sector in Pakistan. International Research Journal of Finance and Economics, 47(1), 156-169.

35.Richards, V. D., \& Laughlin, E. J. (1980). A cash conversion cycle approach to liquidity analysis. Financial Management, 9(1), 32-38.

36.Sharma, A. K., \& Kumar, S. (2011). Effect of working capital management on firm profitability empirical evidence from India. Global Business Review, 12(1), 159-173.

37.Summers, B., \& Wilson, N. (2000). Trade credit management and the decision to use factoring: An empirical study. Journal of Business Finance \& Accounting, 27(1-2), 37-68.

38.Stewart, G. B. (1994). EVA: Fact and fantasy. Journal of Applied Corporate Finance, 7(2), 771-84.

39.Takon, S. M., Ugwa, J. M., \& Atseye, F. A. (2015). Effect of working capital management on firm profitability in selected Nigerian quoted companies. International Journal of Economics, Commerce and Management, 3(10), 414-438.

40.Ukaegbu, B. (2014). The significance of working capital management in determining firm profitability: Evidence from developing economies in Africa. Research in International Business and Finance. Available Online: https://www.sciencedirect.com/science/article/pii/S0275531913000779

41.Vahid, T. K., Mohsen, A. K., \& Mohammadreza, E. (2012). The impact of working capital management policies on firm's profitability and value: Evidence from Iranian companies. International Research Journal of Finance and Economics. Available Online: file:///C:/Users/Hani\%20Qasem/Downloads/ ThelmpactofWorkingCapitalManagementPoliciesonFirms.pdf

42.Walker, E. W. (1964). Toward a theory of working capital. The Engineering Economist, 9(2), 21-35.

43.Wasiuzzaman, S. (2015). Working capital and profitability in manufacturing firms in Malaysia: An empirical study. Global Business Review, 16(4), 545-556.

44.Weinraub, H. J., \& Visscher, S. (1998). Industry practice relating to aggressive conservative working capital policies. Journal of Financial and Strategic Decision, 11(2), 11-18.

45.Yazdanfar, D., \& Öhman, P. (2014). The impact of cash conversion cycle on firm profitability: An empirical study based on Swedish data. International Journal of Managerial Finance, 10(4), 442-452.

46.Zariyawati, M. A., Annuar, M. N., Taufiq, H., \& Rahim, A. A. (2009). Working capital management and corporate performance: Case of Malaysia. Journal of Modern Accounting and Auditing, 5(11), 47-54. 